\title{
実験的糸球体腎炎に招ける免疫複合体処理能の検討
}

\author{
川崎克俊・宮崎 滋・矢尾板永信・木原 達*
}

\begin{abstract}
Role of macrophages and polymorphonuclear leukocytes via $F_{c}$ receptors on degradation of preformed soluble immune complexes Preformed soluble immune complexes (ICs) of various sizes were incubated with peritoneal macrophages $(\mathbf{M} \phi \mathbf{s})$ and polymorphonuclear leukocytes (PMNs) from control and nephritic rats at $37^{\circ} \mathrm{C}$ for $1 \mathrm{hr}$ to $24 \mathrm{hr}$ and the rate of ICs degradation was studied.

Immune complexes, being soluble in antigen excess of double, five and twenty times were made of either heterologous (rabbit) antibodies or homologous antibodies with ${ }^{125}$ I-labeled BSA.

In control cells, the degradation rate by either $\mathrm{M} \phi \mathrm{s}$ or PMNs reached the maximum when poorly soluble ICs of double antigen excess were used, and lower level at ICs of 5 times antigen excess. ICs of 20 times antigen excess were almost nondigestible and there was no difference with the control (BSA + normal rabbit sera). Optimal cell number and antibody concentration were those of more than $5.0 \times$ $10^{6} \mathrm{cell} / \mathrm{m} l$ and the amount larger than $35.0 \mu \mathrm{g} / \mathrm{m} l$ antibodies, respectively. As expected, addition of fresh autosera or guinea pig complement to the test tubes resulted a two-fold increase in the rate of the degradation.

When cells were tested from rats at various points in the course of glomerulonephritis, both M $\phi$ s and PMNs were shown to degradate ICs in the way as same as the control. There was no evience of less ICs digestibility among cells from rats with the severest glomerulonephritis. While, less degradation was shown with ICs made of homologous antibodies when $\mathrm{M} \phi$ s and PMNs from the control rats were incubated with, further study is necessary.

These observations indicate that PMNs do digest large quantities of ICs through their $\mathrm{Fc}_{\mathrm{c}}$ receptors just as same as $\mathrm{M} \phi \mathbf{s}$ in vitro. The results were the same when the source of PMNs not only from the control rats but also from rats with severe glomerulonephritis was used.
\end{abstract}

Katsutoshi Kawasaki - Shigeru Miyazaki • Eishin Yaoita - Itaru Kihara

Department of Pathology, Institute of Nephrology Niigata University School of Medicine

key words: glomerulonephritis, immune complex, degradation, phagocytes, Fc receptor

慢性血清病型腎炎モデルは, ヒトの腎疾患を理解する らえで有用なモデルであると考学られている ${ }^{(2)}$ ．流血 中の免疫複合体 (CIC) の大部分は mononuclear phagocyte system (MPS) で処理されているといわれてい $る^{4,5)}$.

筆者らは, ラットに BSA (bovine serum albumin) を抗原として慢性血清病型腎炎を作らせた際 ${ }^{6)}$, 肝・肺 に大量の IC の局在と多数の多形核白血球 (PMNs) 浸潤 が電顕上観察されること7), autoradiography で PMNs の胞体内に IC が貪食されていること息を示しえた（図 1).これらの成績から MPS のみならず, 流血中の白 血球による IC の処理も重要と考えられる，そこで腎 炎惹起過程に扫けるIC の処理能を腹腔渗出細胞 (PMNs, macrohages), および buffy coatsを用いて

\footnotetext{
$*$ 新潟大学医学部付属腎研究施設病理形態学部門
}

in vitro で検討を加えたので報告する．

\section{方 法}

\section{（1）BSA 腎炎の作製}

8 週秢の雄性 SHR (spontaneous hypertensive rats) ラット25匹に BSA $1 \mathrm{mg}$ を complete Freund's adjuvant で免度し， 8 週目より 12 週目まで連日 BSA $2 \mathrm{mg}$ を静 注して腎炎を作製した ${ }^{6}$ （図 2 ）。各週（8１2週）のは じめに, BSA 静注後 24 時間目に 5 匹ずつ屠殺して, 各 細胞および血液を採取し，血清分離し，実験に供した。 control 群は, 正常ラットを毎週各 3 匹ずつ屠殺し, 細 胞と血清を採取し行った。

\section{（2） IC の作製}

BSA chloramine $\mathrm{T}$ 法により ${ }^{125} \mathrm{I}$ で標識し, 家 鬼に BSA complete Freund's adjuvant と免疫して 


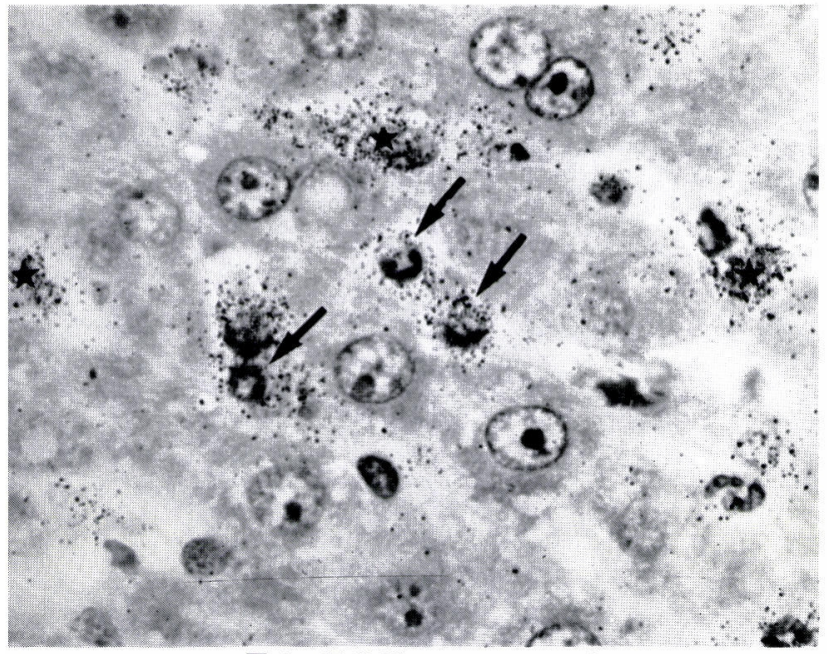

図 1 旰光顕オートラジオグラフィー

Kupffer 細胞に多量の銀粒子を認める（ネ）注多形 核白血球上にも銀粒子の取り込みがみられる(ん).9週 実験群（HE染色，×400）
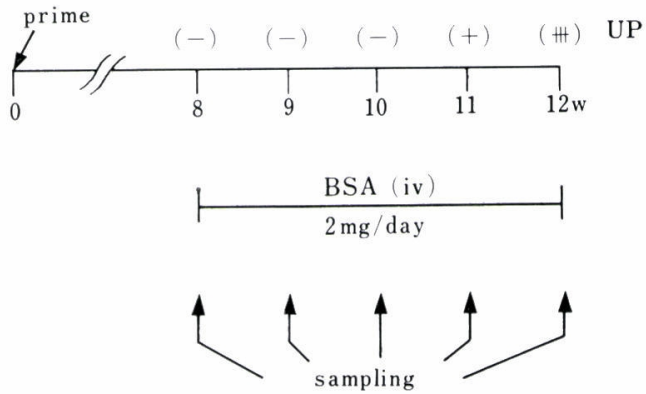

Exp. 1: PEC, buffy coat Exp. rat IC ${ }^{*} \mathrm{BSA}-\mathrm{aBSA}$ (Rabbit)

Exp. 2: PEC, buffy coat normal rat IC *BSA-aBSA (Exp. rat)

図 2 experimental protocol

$1 \mathrm{mg}$ BSA/CFA で prime した後，8週目より 12 週目まで BSA $2 \mathrm{mg}$ を連日静注して腎炎を作製し た。尿蛋白の出現を“up”で示した，各週のはじめ に各細胞，血清を sampling した。

作製した抗体を用いて，当量（抗体量 $=35.0 \mu \mathrm{g} / 0.5 \mathrm{ml}$ ) tube), 5 倍抗原過剩, 20 倍抗原過剩の IC を作製した. すべての実験は抗原量を一定 $(20 \mu \mathrm{g} / 0.5 \mathrm{ml} / \mathrm{tube})$ 下で 行い, $10,000 \sim 20,000 \mathrm{cpm} /$ tube になるよ ${ }^{125} \mathrm{I}-\mathrm{BSA}$ の割合を調整した。抗 BSA 抗体価は, 定量沈降反応法 により，親和性はABC-33法により検討した。

一方, 腎炎惹起過程のラット血清を用いて, homologous IC を in vitro で同様に作製した。なお, IC の size は抗体価のもっとも高い 9 週の血清で当量となるよ ら調整した。 したがって，他の週は抗原過剩の IC とな るが，どの週も抗原量を一定にして作製した。

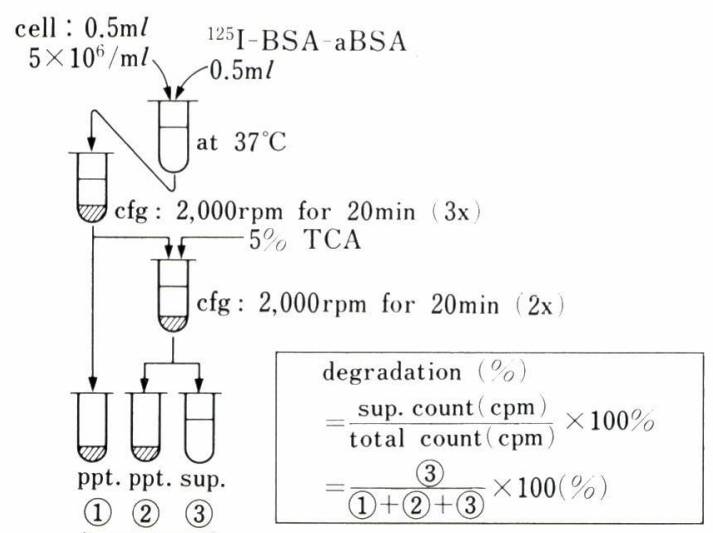

図 3 incubation protocol
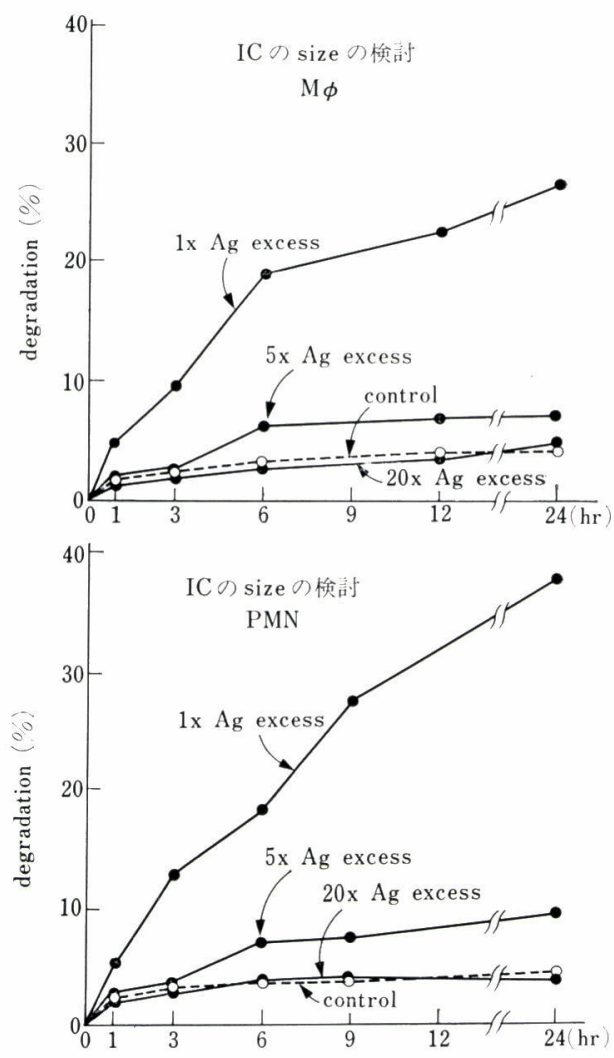

図 4 IC 9 size $の$ 検討

（3）細胞の調整

$0.1 \%$ glycogen 刺激後, 4 時間目のラット腹腔より 採取した non adherent all をPMNsとして, 4 日目 の adherent cell を macrophages として用いた。 また heparinize した血液から遠心して得られた buffy coat も実験に供した。

(4) IC の処理・測定

おのおのの細胞を $5.0 \times 10^{6} / \mathrm{ml}$ に調整し，作製した 


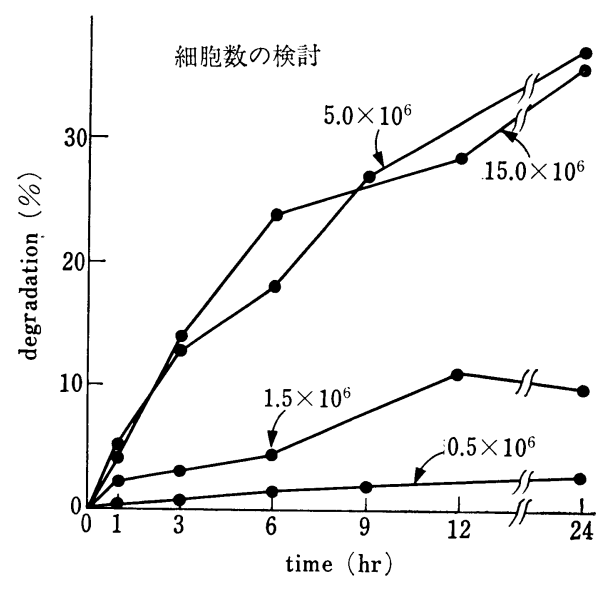

図 5 細胞数の検討

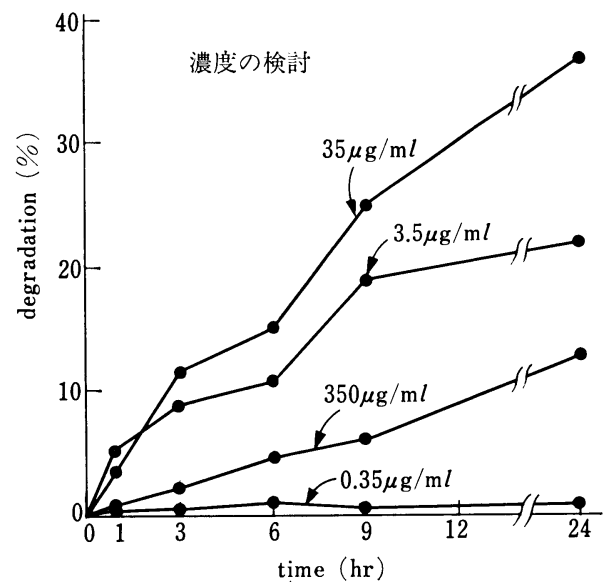

図 6 至適濃度の検討

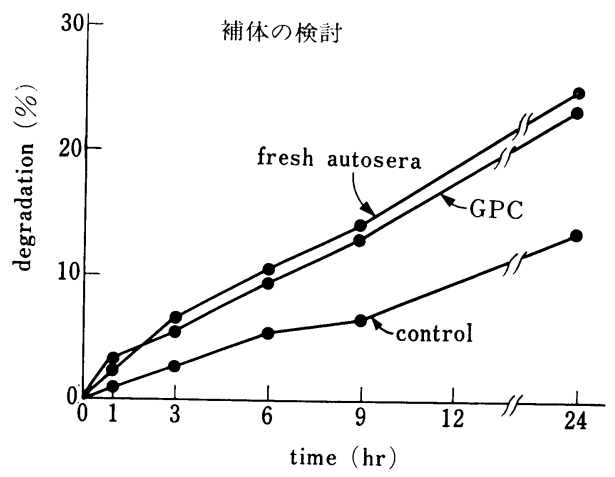

図 7 補体の検討

IC と $0.5 \mathrm{~m} l$ ずつポリスチレンチューブに混合し, $37^{\circ} \mathrm{C}$ 恒温槽内で $1 \cdot 3 \cdot 6 \cdot 9$ (or 12)・24 時間 incubate した. incubate 後, Hanks 液で 2,000 rpm 20 分遠心 して 3 回洗い，細胞成分を沈椬として 分離し，上清に trichloroacetic acid を最終濃度5.0\%になるよう調整し， 再び 2,000rpm 20分遠心して 2 回洗った後，上清と沈
椬を分離した. 各上清および沈椬中の ${ }^{125} \mathrm{I}$ のカウント をとカウンターで測定後, 図 3 のごとく degradationの 割合を計算し, degradation index とした. sampling は すべて triplicate で行い, 平均值で表示した.

\section{結 果}

\section{(1) IC の size の検討}

図4 亿 macrophages と PMNs の IC の処理能を示 した，両者とも当量の poorly soluble IC でもっとも高 い degradationを示した。 24 時間では macrophages 26.5\%, PMNs 37.2\% で PMNs のほうがより高い傾向 を示した，5倍抗原過剰の IC では，それぞれ 7.0\%， 8.8\%，20倍過剩では，4.0\%，3.6\% で degradationは IC の size すなわち lattice が小さくなるにつれて減少 し, macrophages, PMNs の間にも差はなかった。なお， 抗体ではなく normal rabbit sera を等量入れて 作製し た control 群では, macrophges $2.9 \%$, PMNs 3.5\%と 非常に低く，20 倍抗原過剰 IC と同様の degradation を示した。

\section{（2） 細胞数の検討}

戍 5 に PMNs の例を示した. $1.0 \times 10^{5} / \mathrm{ml}$ 以下では 有意な処理がみられなかったため, $5.0 \times 10^{5} / \mathrm{m} l$ 以上の

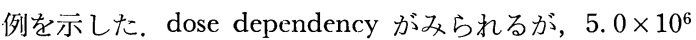
之 $1.5 \times 10^{7} / \mathrm{ml}$ では有意差はみられなかった。なお， この実験も含めて cell viability は trypan blue dye exclusion test で95\%以上で行った.

\section{（3）至適濃度の検討}

当量の IC を用いて濃度を 10 倍ずつ段階稀䣋して, 抗体量に換算して $0.35 \mu \mathrm{g} / \mathrm{m} l \sim 350 \mu \mathrm{g} / \mathrm{m} l$ の幅で検討 した. $0.35 \mu \mathrm{g}$ 以下の稀釈では, ${ }^{125} \mathrm{I}$ の濃度も下がり, 测定不能であった。濃度の上昇につれ degradation は 克進し, $35.0 \mu \mathrm{g} / \mathrm{ml}$ で最高值を示したが, さらに高濃 度の $350 \mu \mathrm{g} / \mathrm{ml}$ では抑制を示した（図 6 ）。

\section{(4) 補体の検討}

乾燥モルモット補体 (GPC) と autologous fresh sera を用いて当量 IC に抢ける degradation を検討し た（図7). GPC は lotにより差を認めたが, 増強作 用のある lot では autologous sera と同様に 2 倍程度 の増強作用を示した。

（5）腎炎惹起過程の各週の細胞における IC 処理の 検討

macrophages の IC degradation は，24時間で 60 80\%に達し，10１1週にやや高值の傾向を認めた(図8). control 群は normal ratに ICを取り込ませたもの で，各週とも control 群と大きな差は認めず，十分な 処理能を示した.

なお, IC は当量の poorly soluble IC の degradationを図示してある.PMNs では24時間で $60 \%$ 前後の 


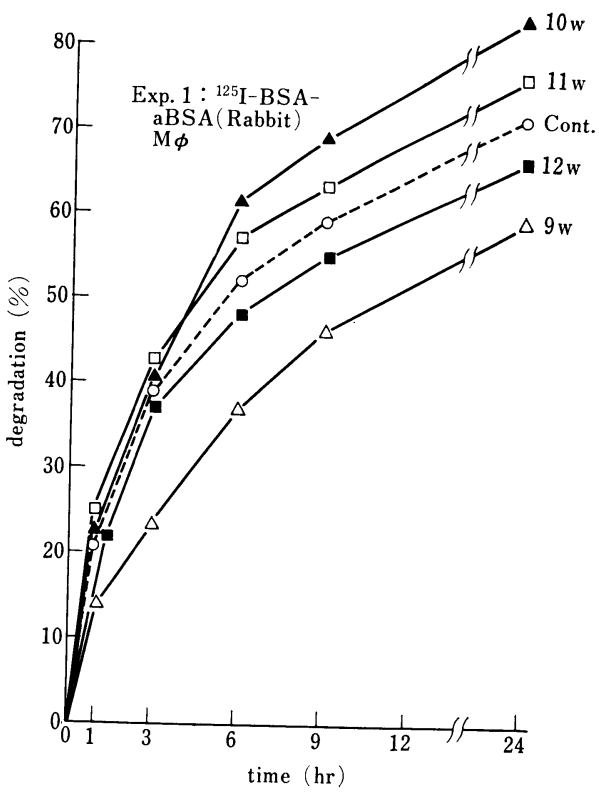

図 8 腹腔 macrophages に打けるIC 処理能 の検討

家鬼抗 BSA 抗体によるICを用いた例. 各週の細胞とも著明な degradationを示 している.

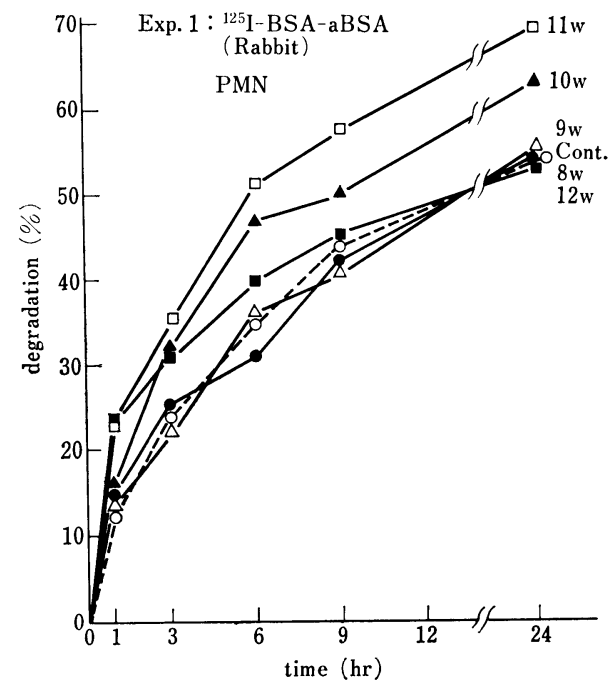

図 9 多形核白血球の IC 処理能の検討 家鬼抗 BSA 抗体に上る ICを用い た例。どの週も著明な degradationを 示している.

degradation を示し, やはり 10〜11 週でやや高値の傾 向を示したが，各週間の差は認められなかった（図 9 ). buffy coat は macrophages PMNs にくらべ degradation は低く24時間で25〜50\%の值を示した（図10）.

（6）腎炎若起過程の各週の血清による IC 処理能 の検討

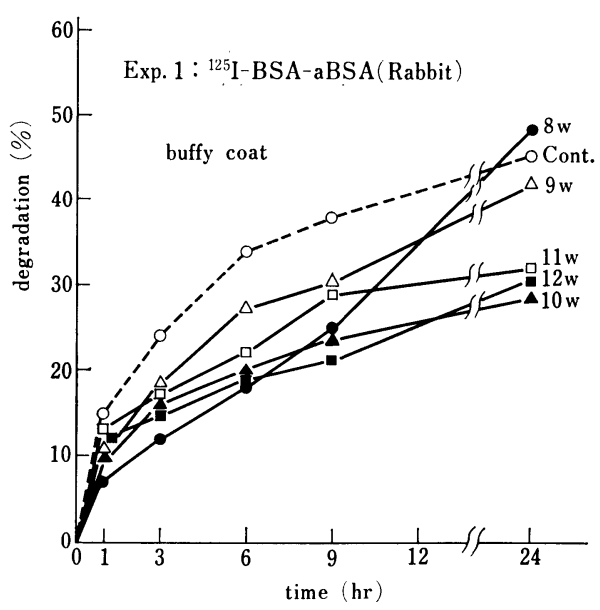

図 10 buffy coat に打ける IC 処理能の 検討 家刺抗 BSA 抗体によるICを用いた例。 PMNs macrophages にくらべ, degradation は低い傾向にあるが，週ごとに大きな 差はない。

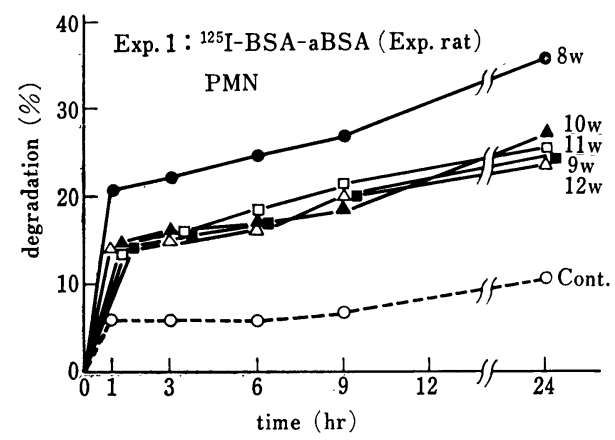

図 11 多形核白血球に打けるIC 処理能の検討 各週の homologous sera を用いて， nomal rat の IC degradation を測定した 例. 家鬼抗体を用いた IC にくらべ， degradation は著明に低い。

ラットの homologuos sera による IC を用いた系で は, 正常ラットの degradation を各週の ICを加えて みたが，図11に示すように，どの週も低く9 週目では当 量 IC にもかかわらず，20\%程度にとどまった．この傾 向は, macrophges, buffy coat にもみられた。また，各 週で IC の size が異なるにもかかわらず，週による差 を見いだせなかった。

\section{考 按}

従来より流血中の IC の処理には, MPS が主体的に 役割を演じていると考えられ，PMNs の役割について は，いまだ報告が少ない。

筆者らは, 慢性血清病型腎炎モデルに打いて PMNs の関与を in vivo ${ }^{7,8)}$ で検討してきたが，今回 in vitro に おいても macrophages と同様の IC 処理能を有してい 


\section{ることを呈示することができた．}

すなわち，腎炎惹起過程の各週においても，PMN の IC 処理能は十分に保たれており，低下は見出せなかッ た。これは PMNs の骨髄からの動員能と turn over の 早さを反映するものであり，連日の抗原投与に抎いて も，ICを十分処理し，しかもその割合は，従来よりい われてきた MPS の IC 処理に匹敵するレベルを維持 しているものと思われる。ささらに，流血中にある monocyte と PMNs の比を考学る PMNs による処理は大 きいものと考光られる。

一方, 腹腔 macrophage も, PMNs にくらべ生体内 に拈ける turn over がながいにもかかわらず，各週で 十分な IC 処理能を示しており，Fc レセプター $(\mathrm{FcR})$ の十分な機能が保たれていることを示している．西ら は, Rosette formation により肝の Kupffer cell の FcR と $\mathrm{C}_{3}$ レセプター $\left(\mathrm{C}_{3} \mathrm{R}\right)$ 機能を検討しているが, $\mathrm{IC}$ 暴 露後 2 時間で receptor activity は最低となっているが, 6 時間目ですでに回復傾向を示し，24時間目には $80 \%$ 程 度に回復していることより，筆者の実験系でも BSA 静 注後, 24 時間目に採取した macrophags の in vitro で の IC 処理能は十分保たれていることを証拠づけるもの と考えられる。

食細胞の $1 \mathrm{C}$ の処理能は, 従来より $\mathrm{FcR}^{10 \sim 15)}$ と $\mathrm{C}_{3} \mathrm{R}^{16 \sim 19)}$ を介すると考えられている. GPC と新鮮ラッ ト血清による IC の degradation 増強作用がある場合を 示したが，in vivoで IC の処理が補体で増強されない報 告 ${ }^{13}{ }^{20)}$ や, in vitro でも stimulated macrophages では 補体による増強作用がみられない場合 ${ }^{21)}$ も存在すること が知られており，今回は，腎炎における IC 処理能をみ る系では, FcR の関与のみにしぽって行った。

preliminary の検討で当量, 5 倍, 20 倍抗原過剩の IC の 3 段階で degradation を調べたが，腎炎の存在下で は, 光顕による細胞内沈着物の観察, 電顕上 dense deposits の観察結果から, in vivo では poorly soluble〜 insoluble IC が組織内 に生じていることが考えられ, degradation の割合も高かった点を考慮し, 今回は poorly soluble の IC で腎炎若起過程の IC 処理能を 検討した。 この IC の size は, Hawkins と Peetersの 報告 ${ }^{22)}$ にもあるように, 白血球からの enzyme release がもっとも効果的に起こる size であり, 処理をみるう えでよい marker と考えられる。

in vivo では, 肝・肺の IC の分布が腎炎惹起過程の 早期に強く起こる ${ }^{23)}$ ので, PMNs, macrophages のほか に, 組織固着 macrophages の処理能の検討も必要であ ろう. Daha と van $\mathrm{Es}^{24)}$ は in vitro で monocyte にく らべ, peritoneal macrophage と Kupffer cell が 10 倍 も IC の degradation が高いことを報告している。 し かも，補体の影響については，分離 した Kupffer cell
の場合, fresh sera で抑制され，40時間の incubate 後 では， $\mathrm{C}_{3} \mathrm{bR}$ が再び表出され，はじめて補体レセプター を介する処理が无進すると報告している，腎炎惹起過程 で検討の必要を感ずる興味ぶかい報告である。

今回の実験では，homologous ICを用いた IC degradation が非常に低く，有意な貪食能を示しえなかっ た，濃度の検討に問題がある可能性があるが，10倍濃縮 IC を用いても同様の結果を得た。これは家鬼抗 BSA 抗体にくらべ, ラットの抗体では抗体価・親和性が低い ことにより degradationをみるらえでの最適の IC を 作製できなかった可能性が強い。この点に関しては，さ らに IC の量, size など性状の再検討が必要であると 考えている.さらに, BSA 静注直後の循環中にある IC を取りだし，実験に用いる方法も考慮中である。

な特，本研究の一部は文部省昭和60年度科学研究費補 助金(奨励研究(A)) No.60770266により行った.

\section{文 献}

1) Germuth, F.G.: A comparative histologic and immunologic study in rabbits of induced hypersensitivity of the serum sickness type. J. exp. Med. 97: 257-282, 1953.

2) Dixon, F.J., Feldman, J.D., Vazquez, J.H.: Experimental glomerulonephritis: The pathogenesis of a laboratory model resembling the spectrum of human glomerulonephritis. J. exp. Med. 113: 899-920, 1961.

3) Brentjens, J.R., O'Connel, D., Albini, B., Andres, G.A.: Experimental chronic serum sickness in rabbits that received daily multiple and high dose of antigen: a systemic disease. Ann. N.Y. Acad. Sci. 254: 603-613, 1975.

4) Haakenstad, A.O., Mannik, M.: Saturation of the reticuloendothelial system with soluble immune complexes. J. Immunol. 112: 19391948, 1974.

5) Hoffsten, P.E., Sverdin, A., Bartel-, M., Hill, C.L., Venverloh, J., Brotherson, K., Klahr,S.: Reticuloendoselial and mesangial function in murine immune complex glomerulonephritis. Kidney Int. 15: 144-159, 1979.

6) Yamamoto, T., Kihara, I., Morita, T. Oite, T.: Bovine serum albumin (BSA) nephritis in rats. I. Experimenal model. Acta Pathol. Jpn. 28: 859-866, 1978.

7) Miyazaki, S., Kawasaki, K., Yaoita, E., Yamamoto, T., Kihara, I.: Bovine serum albumin nephritis in rats. V. Kinetic studies of antigen localization in various organs and the phagocytic role of polymorphonuclear leukocytes. Am. J. Pathol. 119: 412-419, 1985.

8) Kawasaki, K., Miyazaki, S., Yamamoto, T., Kihara, I.: Identifiation and quantitation of cells that process immune complexes in ne- 
phritic rats induced with bovine serum albumin J. Leukocyte Biol.(in press)

9) Nishi, T., Bhan, A.K., Collins, A.B., McCluskey, R.T.: Effect of circulating immune complexes on Fc and C3 receptors of Kupffer cells in vivo. Lab. Invest. 44: 442, 1981.

10) Berken, A., Benacerraf, B.: Properties of antibodies cytophilic for macrophages. J. exp. Med. 123: 119, 1966.

11) Messner, R.P., Jelinek, J.G.: Receptors for human $\gamma \mathrm{G}$ globulin on human neutrophils. J. clin. Invest. 49: 2165, 1970.

12) Phillips-Quagliata, J.M., Levine, B.B., Quagliata, F., Uhr, J.W.: Mechanisms underlying binding of immune complexes to macrophages. J. exp. Med. 133: 589, 1971

13) Arend, W.P., Mannik.: In vitro adherence of soluble immune complexes to macrophages. J. exp. Med. 136: 514, 1972.

14) Leslie, R.G.Q., Alexander, M.D., Cohen, S.: Binding of immune complexes of guinea pig IgG2 to homologous exudate cells. Eur. J. Immunol. 6: 841, 1977.

15) Knuston, D.W., Kijlstra, A., van Es, L.A.: Association and dissociation of aggregated IgG from rat peritoneal macrophages. J. exp. Med. 145: 1368, 1977.

16) Lay, W.H., Nussenzweig, V.: Receptors for complement on leucocytes. J. exp. Med. 128: 991, 1968.

17) Huber, H., Fudenberg, H.H.: The interaction of monocytes and macrophges with immunoglobulins and complement. Ser. Haematol.
2: 160,1970 .

18) Mantovani, B., Rabinovitch, M., Nussenzweig, V.: Phagocytosis of immune complexes by macrophages. J. exp. Med. 135: 780, 1972.

19) Kijlstra, A., van Es, L.A., Daha, M.R.: Enhanced degradation of soluble immunoglobulin aggregated by macrophages in the presence of complement. Immunology 37: 673, 1979.

20) Arend, W.P., Mannik, M.: Studies on antigenantibody complexes. II. Quantification of tissue uptake of soluble complexes in normal and complement-depleted rabbits. J. Immunol. 107: 63-75, 1971.

21) Daha, M.R., van Es, L.A.: Complement-dependent inhibition of degradation of soluble immune complexes and immunoglobulin aggregates by thioglycollate-stimulated peritoneal macrophages. Immunology 50: 107, 1983.

22) Hawkins, D., Peeters, S.: The response of polymorphonuclear leukocytes to immune complexes in vitro. Lab. Invest. 24: 483, 1971.

23) Miyazaki, S., Kawasaki, K., Yaoita, E., Yamamoto, T., Kihara, I.: Bovine serum albumin (BSA) nephritis in rats: III. Antigen distribution in various organs. Clin. exp. Immunol. 59: 293-299, 1985.

24) Daha, M.R. van Es, L.A.: Fc and complement receptor-dependent degradation of soluble immune complexes and stable immunoglobulin aggregates by guinea pig monocytes, peritoneal macrophages, and Kupffer cells. J. Leukocyte Biol. 36: 569-579, 1984. 